\title{
Phylogenetic Study of Lempuk Fish (Gobiopterus sp.) in Ranu Grati Based on Mitochondrial DNA Sequence of Cytochrome Oxidase I (COI) Barcoding Region
}

\author{
Abd Rahem Faqih ${ }^{1 *}$, Wahyu Endra Kusuma ${ }^{1}$, Septi Anitasari ${ }^{2}$ and Dian Kartika Sari ${ }^{1}$ \\ ${ }^{1}$ Aquaculture Study Program, Department of Aquatic Resources Management, Faculty of Fisheries \\ and Marine Sciences, Universitas Brawijaya, Jl. Veteran, Malang 65141, Indonesia \\ ${ }^{2}$ Aquatic Resources Management Study Program, Department of Aquatic Resources Management, \\ Faculty of Fisheries and Marine Sciences, Universitas Brawijaya, Jl. Veteran, Malang 65141, \\ Indonesia
}

*Correspondence :

ar.faqih@ub.ac.id

Received : 2020-11-11

Accepted : 2021-05-08

Keywords :

Ranu Grati, Lempuk fish, COI, Phylogenetic, Genetic distance

\begin{abstract}
Lempuk fish (Gobiopterus sp.) is one of the local species in Ranu Grati. The high level of Lempuk fishing and the low level of awareness of the Grati community on the importance of conservation and domestication efforts, as well as the taxonomy of the fish itself, have threatened the population. Therefore, long-term efforts should be undertaken to preserve and identify the origin of Lempuk fish by conducting a molecular phylogenetic study based on COI. This study aimed to determine, analyze and describe the kinship and phylogenetic relationships of Lempuk fish (Gobiopterus sp.). This study used a descriptive method, starting from the specimen collection, extraction by the Phenol-Chloroform method, and amplification by the PCR method, to the screening process. The data analysis method used the MEGA 5 application. The phylogenetic study used the Maximum Likelihood method with a bootstrap value of 1.000 times. The results showed that the intra-population genetic distance of Lempuk fish is low at $0.00 \%$. Genetic distance between the population of Lempuk fish is relatively high with $G$. brachypterus from Malaysia of $22.4 \%$, Central Java of $21.5 \%$, and India of $21.4 \%$ and with G. lacustris from Malaysia of $22.5 \%$, the Philippines of $21.6 \% \%$, Thailand of $19.7 \%$, and with G. chuno and G. semivestitus of $21.2 \%$ and $23.6 \%$ accordingly. The phylogenetic study obtained showed the formation of a separate group that is different between the Lempuk fish group and other Gobiopterus fish, supported by a bootstrap value of $99 \%$.
\end{abstract}

\section{INTRODUCTION}

Lempuk fish (Gobiopterus sp.) are classified as fish with high economic value (Roesma et al., 2020) and are one of the endemic biodiversity richness in Ranu Grati with a length of about $2-3 \mathrm{~cm}$ and a transparent shape, so only the eyes and the internal organs can be seen (Bramestian et al., 2016). This fish has a character similar to that of $G$. branchyopterus and G. chuno (Kottelat et al., 1993). Morphological characters of Gobiopterus sp., according to Larson et al. 
(2008), include having a short and wide head, a round snout, relatively small teeth, pointed and conical shape, so it is not surprising that this fish is known as 'vampire fish' (Hadiaty et al., 2012). Gobiopterus sp. belongs to the Gobiidae family of the Actinopterygii class (Kottelat, 1993) with distribution areas including Java, Sumatra, the Philippines, Malaysia, India, and Australia.

Its distribution on the island of Java is not in all freshwaters but is only limited to Ranu Grati, so the lake becomes a natural habitat for Lempuk fish. This fish is known to the people around Ranu Grati, Pasuruan Regency as an icon of Ranu tourism. Lempuk fish is processed as food so that it has economic value and becomes a source of income for the local community. However, the catch of Lempuk fish is currently starting to decline. Conservation efforts for Lempuk fish are also still low, and no further action has been taken to cultivate these fish (Imam, 2011).

Apart from overfishing, the existence of local Indonesian fish is threatened due to the entry of invasive alien species (Hasan et al., 2020a; Hasan et al., 2020b). Along with the high rate of fishing for Lempuk fish, low level of public awareness of the importance of conservation and domestication efforts, and the lack of knowledge about the identification, diversity, and taxonomy of these fish, the population is getting more threatened (Imam, 2011).

Long-term efforts that can be made to preserve and identify the origins of the Lempuk fish are to conduct a phylogenetic study. The study aims to understand the level of kinship between organisms, the life history of a species, evolutionary relationships, and their identification (Hasibuan et al., 2017). The molecular method that can be used for the phylogenetic study of a species-level evolutionary branch is the mitochondrial Cytochrome Oxidase Subunit I (COI) gene (Wirdateti et al., 2016). COI gene is a DNA barcode that has a superiority in studying genetic characteristics because it has a part that is sustainable and has few deletions and insertions in its sequence as well as a greater range of phylogenetic signals than other mitochondrial genes. Therefore, this method can be used for the phylogenetic study of Lempuk fish (Gobiopterus sp.) in Ranu Grati Pasuruan. As in many other studies on local fish, the results of this study are expected to contribute to local fish conservation efforts in Indonesia (Widodo et al., 2020; Hasan et al., 2019).

\section{METHODOLOGY}

\section{Place and Time}

The specimen collection used was taken from the central waters of the lake with 5 coordinate point stations at Ranu Grati Pasuruan, East Java.

The analysis was carried out at the Hydrology Laboratory of the Fish Resources Division, Faculty of Fisheries and Marine Sciences, and at the Physiology Laboratory and Biomedical Laboratory, Faculty of Medicine, Universitas Brawijaya in SeptemberDecember 2019.

\section{Research Materials}

This study used a coolbox, portable aerator, Bunsen, Sprayer, scales, trash can, cold centrifuge, electrophoresis, documentation gel, PCR Thermal cycler, UV tray, oven, and micropipette. The materials used were TNESU8 buffer, 5M $\mathrm{NaCl}$, sterile Aquades, Phenol: Chloroform (1:1), Chloroform: Iscamylalcohol (24:1), Ethanol (98-100\%), Ethanol 70\% Agarose, TAE 1x, Primer FishF1 and FishR1, GoTaq PCR mix, ddH2O, DNA test template, Ethidium bromide, Loading dye, and Proteinase-K.

\section{Research Design}

The working method and analysis used in this research activity is a descriptive method that describes the phylogenetic and kinship relationships of fish Gobiopterus spp. at Ranu Grati with several parameters. 


\section{Work Procedure}

\section{Specimen Collection}

Specimen collection was carried out at 5 coordinate stations in Ranu Grati Pasuruan, East Java. Specimens were taken using a shovel from FADs in the waters. The specimens were then killed through the cooling process using ice cubes and later were preserved using 96\% alcohol and stored in the freezer before the molecular test stage was carried out. Afterward, the specimen preparation process was carried out by cutting the pectoral fins or the right side of the flesh. The fin pieces were then put into a $1.5 \mathrm{ml}$ microtube containing $96 \%$ ethanol solution.

\section{Stages of DNA Extraction Molecular Test}

The process of molecular testing was carried out by sending DNA samples to PT. Genetika Science Indonesia and the sequencing process was carried out at the 1st BASE DNA Sequencing Service in Singapore using the dye terminator sequencing method based on sanger sequencing. This method is the first method of sequencing with the results of sequence lengths ranging from 1,000 to 1,200 base pairs (Tasma, 2015).

\section{Data Analysis}

The data analysis process was carried out with software on a laptop. The electropherogram data from the sequencing process was edited using the software Chromas v.2.6.6., UGENE, MESQUITE v.3.5.1., DNASp, Network 5.1.0.8. and phylogenetic study using MEGA 5 application (Tamura et al., 2011) with maximum likelihood method and bootstrap value. Maximum likelihood is a phylogenetic tree reconstruction method with the principle of determination of tree topology, branch length, and evolutionary model (Felsenstein, 1981). This method can be used with large amounts of data with a maximum estimation approach and bootstrap replication so that a precise evolution tree is formed (Dhar and Minin, 2016).

\section{RESULTS AND DISCUSSION Specimen Collection}

Lempuk fish (Gobiopterus sp.) specimens were taken from Ranu Grati Pasuruan, East Java with 5 stations located in the middle of the lake. The collection of Lempuk fish used FADs or fishing gears installed by local fishermen. The number of samples that underwent sequencing was 1 fish from each station, taken randomly.

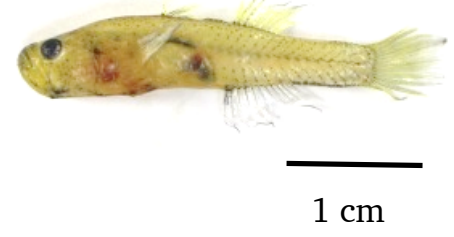

Figure 1. Lempuk fish specimen.

Molecular Analysis

Results of DNA Extraction and Amplification

Based on the results of DNA extraction, it was obtained that the values for the DNA quality were quite pure, as shown in Table 1. Amplification was carried out using the PCR (Polymerase Chain Reaction) method with the COI coding gene with forwarding Fish F1 and reverse Fish R1 primers based on the research of Heather and Chain (2016). The advantages of the COI gene are the high rate of evolution and the ability to 
distinguish species-level organisms. The results of the visualization of the PCR product produced DNA bands that were quite good, so it can be said that the results of the amplification process went well and showed the purity of the DNA obtained. The level of purity and success of amplification are indicated by the genome band above the marker (Fahmi et al., 2017). Based on Figure 3, it can be said that the amplification of the Lempuk fish sample has good results, indicated by the presence of a band with a length of approximately $655 \mathrm{bp}$, fairly thick and visible as shown in Figure 2.

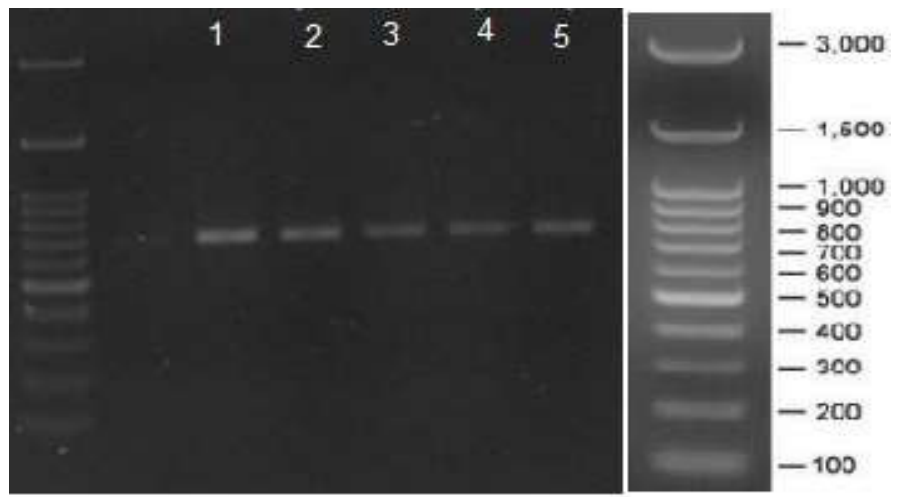

Figure 2. The results of visualization of PCR products from the COI gene of Lempuk fish (Gobiopterus sp.) specimens with a DNA band length of approximately 655 bp.

\section{DNA Sequencing Results}

The results of the sequencing process were sent back in the form of an electropherogram file in $\mathrm{AB} 1$ format. The electropherogram is a diagram of the nucleotide sequence results with the peaks of the graph showing bases. Some of the electropherogram results were in stable images and some were in unstable images (Ismail et al., 2012). A good electropherogram is characterized by no signal peak piled up (Guspratiwi et al., 2019). Moreover, cutting the electropherogram should not be too much as this can cause missing DNA information. The number of nucleotides that are cut should be less than 30 nucleotide nitrogenous bases.

\section{Results of BLAST Analysis}

The results of the BLAST search with the limitation of the algorithm (expected species) are suitable with the genus Gobiopterus. It can be seen in Table 2 . Table 2 shows some of the species that emerged after the BLAST process on the Lempuk fish sample. The results indicate that Lempuk fish can be indicated as a new species that need to be re-identified. This is in line with Hofstetter et al. (2019), suggesting that the category of a species is the same if it has a sequence similarity of $100 \%$. Sequences that have $99 \%$ similarity explain the possibility of related species, while sequences that have $96-99 \%$ or $100 \%$ similarity include closely related species. Meanwhile, according to $\mathrm{Hu}$ and Kurgan (2018), the sequence is included in the genus category when the BLAST result has the highest score of $96 \%$ and in the family category with a score of $<96 \%$.

Table 1. BLAST results of Lempuk fish samples from NCBI.

\begin{tabular}{cccc}
\hline Description & Query Cover & E-Value & Per-Ident \\
\hline G. lacustris & $94-100 \%$ & 0.0 & $82.95-83.15 \%$ \\
G. brachypterus & $97-99 \%$ & 0.0 & $81.86-82.02 \%$ \\
G. chuno & $97-99 \%$ & 0.0 & $81.86-81.98 \%$ \\
\hline
\end{tabular}




\section{Analysis of the Genetic Distance of Lempuk Fish (Gobiopterus sp.)}

Genetic distance is the degree of genetic difference or genomic difference between populations (inter-population), within populations (intra-populations), or on species that is measured numerically (Nei, 1978). Information on specimen data obtained from GenBank and used as a comparison between Lempuk fish species and G. brachypterus, G. lacustris, $G$. chuno and $G$. semivestitus fish species from several different locations, and the specimen code and access number indicating different specimens from several locations can be seen in Table 2 .

Table 2 shows that the genetic distance of Lempuk fish (Gobiopterus sp.) is $0 \%$. This shows that Lempuk fish are a group of similar fish species in a fish population in Ranu Grati. Fish populations of $G$. brachypterus from Malaysia and Java, and G. lacustris from Malaysia and Thailand are also a group of similar species in a fish population with genetic distance values of $0.65 \%$ and $0.22 \%$ respectively, while the data for species of G. lacustris from the Philippines shows a value of $14.26 \%$ marked in bold and one star; this indicates the possibility of not being a group of the same species in the area because of the high intra-population genetic distance value exceeding $3 \%$. The percentage value of genetic distance can indicate how close the kinship of a species is.

The value of genetic distance can be said to be high if the value is close to 1 or has differences between individuals, while the value of the genetic distance is said to be low if it is close to 0 . The condition of the genetic distance value that is close to 0 indicates that there is no difference between individuals or groups, commonly called a monophyletic group. Monophyletic groups can be formed taxonomically with genetic differences of not more than 3\% (Fahmi et al., 2017). A monophyletic group is a group consisting of taxa united by one or more characteristics of fish species that are closely related to a common ancestor (Muzzazinah, 2017).

Table 2. Value of genetic distance intra fish populations.

\begin{tabular}{|c|c|c|c|}
\hline Population location & Species & $\begin{array}{l}\text { Percentage } \\
\text { intra-population } \\
\text { genetic distance }\end{array}$ & STDEV \\
\hline Ranu Grati (RG) & Gobiopterus sp. & $0.05 \%$ & 0.0003 \\
\hline Malaysia (MLY) & & $0.32 \%$ & 0.0018 \\
\hline Jawa Tengah (JAWA) & G. brachypterus & $0.19 \%$ & 0.001 \\
\hline INDIA (INDI) & & $\mathrm{n} / \mathrm{c}$ & $\mathrm{n} / \mathrm{c}$ \\
\hline Malaysia (MLY) & & $0.65 \%$ & 0.0026 \\
\hline Filipina (FLP) & G. lacustris & $14,26 \% *$ & 0.0136 \\
\hline Thailand (THLND) & & $0.22 \%$ & 0.0014 \\
\hline Bangladesh (BLDSH) & G. chuno & $\mathrm{n} / \mathrm{c}$ & $\mathrm{n} / \mathrm{c}$ \\
\hline Australia (AUST) & G. Semivestitus & $\mathrm{n} / \mathrm{c}$ & $\mathrm{n} / \mathrm{c}$ \\
\hline
\end{tabular}

\section{Analysis of Genetic Distances Between the Population of Lempuk Fish and Population of Gobiopterus from GenBank}

The analysis of the genetic distance between the population of Lempuk fish sample and the data of species population from GenBank was carried out using the Pairwise Distances method in MEGA 5.0 (Tamura et al., 2011). Based on Table 5, it is known that the highest genetic distance of Lempuk fish is $23.6 \%$ and the lowest is $19.7 \%$. Such value of the genetic distance can be influenced by geographical constraints which can lead to allopatric speciation due to distant geographical restrictions (Wigati et al., 2003).

Based on the results of the genetic distance value of Lempuk fish, it can be seen that the genetic distance of Lempuk 
fish with $G$. brachypterus, G. lacustris, G. chuno, and $G$. semivestitus is in the medium category. This notion is in line with the standard genetic distance criteria of Nei (1972), suggesting that the value of the genetic distance is divided into three categories: if it is close to 0.010-0.099, it is in a low category; if it is close to 0.1 0.99 , it is in the medium category; and if it is close to $1.00-2.00$, it is in the high category (Akbar and Lubenua, 2018).

The value of the genetic distance of Lempuk fish indicates that Lempuk fish are different taxa from other Gobiopterus fish populations, which is indicated by the high genetic distance value of more than $2 \%$, included in the category of medium genetic distance. Such a range of values indicates that Lempuk fish and other Gobiopterus fish populations have a distant relationship and are different fish species. Meanwhile, a species identification threshold value on DNA Barcoding is $2 \%$ for mammals, and this value is considered the standard limit for fish species.

Table 3. Genetic distance between the population of Lempuk fish and Gobiopterus fish.

\begin{tabular}{|c|c|c|c|c|c|c|c|c|}
\hline Population & Lempuk & $\begin{array}{c}\text { MLY (G. } \\
\text { brachypterus) }\end{array}$ & $\begin{array}{c}\text { JAVA (G. } \\
\text { brachypterus) }\end{array}$ & $\begin{array}{c}\text { INDIA (G. } \\
\text { brachypterus) }\end{array}$ & $\begin{array}{l}\text { MLY (G. } \\
\text { lacustris) }\end{array}$ & $\begin{array}{l}\text { FLP }(G . \\
\text { lacustris) }\end{array}$ & $\begin{array}{r}\text { THLND (G. } \\
\text { lacustris) }\end{array}$ & $\begin{array}{c}\text { BLDSH }(G . \\
\text { chuno) }\end{array}$ \\
\hline Lempuk & & & & & & & & \\
\hline $\begin{array}{c}\text { MLY (G. } \\
\text { brachypterus) }\end{array}$ & $22.4 \%$ & & & & & & & \\
\hline $\begin{array}{c}\text { JAVA (G. } \\
\text { brachypterus) }\end{array}$ & $21.5 \%$ & $16.2 \%$ & & & & & & \\
\hline $\begin{array}{c}\text { INDIA (G. } \\
\text { brachypterus) }\end{array}$ & $21.4 \%$ & $2.1 \%$ & $15.5 \%$ & & & & & \\
\hline $\begin{array}{l}\text { MLY (G. } \\
\text { lacustris) }\end{array}$ & $22.5 \%$ & $0.5 \%$ & $16.3 \%$ & $2.5 \%$ & & & & \\
\hline $\begin{array}{l}\text { FLP (G. } \\
\text { lacustris) }\end{array}$ & $21.6 \%$ & $18.9 \%$ & $11.6 \%$ & 0.186 & $19 \%$ & & & \\
\hline $\begin{array}{c}\text { THLND (G. } \\
\text { lacustris) }\end{array}$ & $19.7 \%$ & $16.1 \%$ & $3 \%$ & $15.1 \%$ & $16.3 \%$ & $9.6 \%$ & & \\
\hline $\begin{array}{l}\text { BLDSH (G. } \\
\text { chuno) }\end{array}$ & $21.2 \%$ & $2.6 \%$ & $14.9 \%$ & $2 \%$ & $2.8 \%$ & $18.5 \%$ & $14.9 \%$ & \\
\hline $\begin{array}{c}\text { AUST (G. } \\
\text { semivestitus) }\end{array}$ & $23.6 \%$ & $26 \%$ & $26 \%$ & $25.5 \%$ & $25.9 \%$ & $24.1 \%$ & $24.8 \%$ & $26.3 \%$ \\
\hline
\end{tabular}

\section{Phylogenetic Study}

The results of the phylogenetic tree reconstruction show a scale of 0.02 , indicating that there is a $20 \%$ sequence difference in the obtained sequences. Lempuk fish form different branches or groups from other Gobiopterus fish and have no different haplotypes supported by a bootstrap value of 71 , as presented in Figure 3 as a red line or Group 1 which forms different groups from other Gobiopterus fish. The magnitude of the bootstrap value and the presence or absence of haplotype diversity can be caused by the number of samples tested.

This can be seen in G. brachypterus and G. lacustris from Malaysia which is supported by bootstrap values of 96 and
47 accordingly, forming Group 2. Meanwhile, Group 3 shows $G$. brachypterus fish from India, and group 4 shows $G$. chuno fish from Bangladesh, supported by bootstrap values of 69 and 100 accordingly. Group 5 shows the monophyletic group of the fish taxa $G$. brachypterus from Java with a bootstrap value of 98, and Group 6 shows the taxa G. lacustris from Thailand and the Philippines with bootstrap values of 99 and 93 accordingly. Moreover, Group 7 shows the monophyletic group of taxa $G$. lacustris from The Philippines supported by a bootstrap value of 71 . The number 71 in the bootstrap indicates that the sequence similarity is $71 \%$. 
The magnitude of the resulting bootstrap indicates the percentage of branch accuracy formed. The percentage value of the branch with a value of more than 80 indicates that the branch is accurate and correct, but on the contrary, if it is below 80 it indicates that the branch can change due to the dominance of the same bases between sequences (Widodo et al., 2018). Meanwhile, according to Rosidiani et al. (2013), the range of bootstrap values between 70-100\% indicates that the chances of clade changes are low.

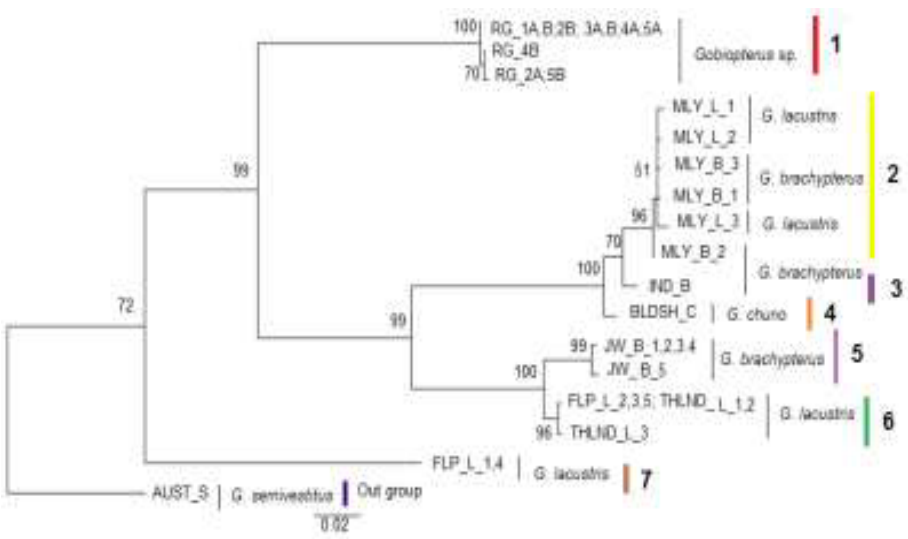

Figure 3. The results of the phylogenetic tree visualization using the ML method.

\section{CONCLUSION}

The value of the intra-population genetic distance of Lempuk fish is $0.00 \%$, and it is relatively low. The value of the genetic distance between populations of Lempuk fish is included in the high category. Based on these results, the population of Lempuk fish forms a separate group from other Gobiopterus fish and does not have a different haplotype, supported by a bootstrap value of 71 . This indicates that a Lempuk fish population is a different group of fish from other Gobiopterus fish.

\section{ACKNOWLEDGMENT}

We would like to express our gratitude to the Faculty of Fisheries and Marine Sciences, Universitas Brawijaya, and Universitas Brawijaya for the funding scheme for the Doctoral Grant of NonHead Lectors (Hibah Doktor Non Lektor Kepala) to the successful completion of this research.

\section{REFERENCES}

Akbar, N.N. and Labenua, R., 2018. Keragaman genetik ikan cakalang (Katsuwonus pelamis) di perairan laut Maluku Utara. DEPIK Jurnal
Ilmu-Ilmu Perairan, Pesisir, dan Perikanan, 7(2), pp.164-176. https:/ /doi.org/10.13170/depik.7.2.1115 6

Bramestian, R.H., Budiarjo and Yurisma, D.Y., 2016. Perancangan place identity Ranu Grati sebagai upaya untuk meningkatkan brand awareness. Jurnal Art Noveau, 6(1), pp.127-136. http://jurnal.stikom.ed u/index.php/ArtNouveau/article/vi ew/2033

Dhar, A. and Minin, V.N., 2016. Maximum likelihood methods for phylogenetic inference. Encyclopedia of Evolutionary Biology, pp.499-506. http://dx.doi.org/10.1016/B978-012-800049-6.00207-9

Fahmi, M.R., Kusumah, R.V., Ardi, I., Sinasari, S. and Kusrini, E., 2017. DNA barcoding ikan hias introduksi. Jurnal Riset Akuakultur, 12(1), pp.29-40. http://dx.doi.org/10.155 78/jra.12.1.2017.29-40

Felsenstein, J., 1981. Evolutionary trees from DNA sequences: a maximum likelihood approach. Journal of Molecular Evolution, 17, pp.368376. https://doi.org/10.1007/bf01 734359 
Guspratiwi, R., Helianti, I., Abinawanto and Nurhasanah, A., 2019. Subkloning gen antigen tuberkulosis 85b dengan menggunakan signal peptide aq1 endoxilanase. Jurnal Cakrawala Kesehatan, 10(2), pp.115-127. https://e-jurnal.anuger ahbintan.ac.id/index.php/ck/article /view/34/33

Hadiaty, R.K., Allen, G.R. and Erdman, M.V., 2012. Keanekaragaman jenis ikan di Teluk Arguni, Kaimana, Papua Barat. Zoo Indonesia, 21(2), pp.35-42. http://dx.doi.org/10.525 08/zi.v21i2.

Hasan, V., Widodo, M.S., Islamy, R.A. and Pebriani, D.A.A., 2020a. New records of alligator gar, Atractosteus spatula (Actinopterygii: Lepisosteiformes: Lepisosteidae) from Bali and Java, Indonesia. Acta Ichthyologica et Piscatoria, 50(2), pp.233-236. http://dx.doi.org/10.3 750/AIEP/02954

Hasan, V., Widodo, M.S., Faqih, A.R., Mahasri, G., Arief, M., Valen, F.S., Tamam, M.B., Yonarta, D., Pratama, F.S. and Fitriadi, R., 2020b. Presence of striped flying barb Esomus metallicus (Teleostei, Cyprinidae) from west Sumatra, Indonesia. Ecology, Environment and Conservation, 26(August Suppl. Issue), pp.S73-S75. http://www.en virobiotechjournals.com/EEC/Vol2 6AugSuppl20/EEC-11.pdf

Hasan, V., Soemarno, Widodo, M.S. and Wiadnya, D.G.R., 2019. Lobocheilos falcifer (Valenciennes, 1842) (Cyrpiniformes, Cyprinidae): distribution extension in Java and first record from Tuntang River, Semarang Regency, Indonesia. Ecology, Environment and Conservation, 25(4), pp.1713-1715. http://www.envirobiotechjournals. com/article_abstract.php?aid $=101$ 27\&iid $=287 \%$ jid $=3$

Hasibuan, F.E., Mantiri, F.R. and Rumende, R.R.H., 2017. Kajian variasi sekunes intraspesies dan filogenetik monyet hitam sulawesi
(Macaca nigra) dengan menggunakan gen COI. Jurnal Ilmiah Sains, 17(1), pp.60-69. https://doi.org/10.35799/jis.17.1.2 017.15558

Heather, J.M. and Chain, B., 2016. The sequence of sequencers: The history of sequencing DNA. Genomics, 107(1), pp. 1-8. https://doi.org/10. 1016/j.ygeno.2015.11.003

Hofstetter, V., Buyck, B., Eyssartier, G., Schnee, S. and Gindro, K., 2019. The unbearable lightness of sequencedbased identification. Fungal Diversity, 96, pp.243-284. https://d oi.org/10.1007/s13225-019-004283

Hu, G. and Kurgan, L., 2018. Sequence Similarity Searching. Current Protocols in Protein Science, 95(1), pp.1-19. https://doi.org/10.1002/c pps.71

Imam, M., 2011. Variasi morfologi pada ikan Lempuk (Gobiopterus branchyopterus) di Danau Ranu Grati Pasuruan. Thesis. Program Studi Bioteknologi Lingkungan. FMIPA Universitas Brawijaya, Malang, $31 \mathrm{p}$.

Ismail, Y.S., Soetjipto, Wasito, E.B. and Nasronudin, 2012. HIV genotype analisis from HIV infection patients in East Java area. Jurnal Natural, 12(2), pp.23-29. http://jurnal.unsyi ah.ac.id/natural/article/view/833/ 771

Kottelat, M., Whiten, A.J., Kartikasari, S.N. and Wirjoatmojo, S., 1993. Ikan air tawar Indonesia bagian barat dan Sulawesi. Periplus edition limitet. Jakarta.

Larson, H.K., Jaafar, Z. and Lim, K.K.P., 2008. An annotated checklist of the gobioid fishes of Singapore. The Raffles Bulletin Of Zoology, 56(1), pp.135-155. https://scholarbank.nu s.edu.sg/handle/10635/100056

Muzzazinah, 2017. Metode filogenetik pada indigofera. Thesis. Jurusan Pendidikan Biologi, Fakultas MIPA, Universitas Negeri Yogyakarta, pp. 25-40. 
Nei, M., 1972. Genetic distance between population. American Naturalist, 106(949), pp.283-292. https://ww w.jstor.org/stable/2459777

Nei, M., 1978. The theory of genetic distance and evolution of human races. Japanese Journal of Human Genetics, 23, pp.341-369. http://dx. doi.org/10.1007/BF01908190

Roesma, D.I., Hong, T.D. and Aidil, D.R., 2020. Phylogenetic analysis of transparent gobies in three Sumatran lakes, inferred from mitochondrial Cytochrome Oxidase I (COI) gene. Biodeversitas, 21(1), pp.43-48. https://doi.org/10.13057 /biodiv/d210107

Rosidiani, E.P., Arumingtyas, E.L. dan Azrianingsih, R., 2013. Analisis variasi genetik amorphophallus muelleri blume dari berbagai populasi di jawa timur berdasarkan sekuen intron trnL. Floribunda, 4(6), pp.129-137. https://doi.org/10.325 56/floribunda.v4i6.2013.102

Tamura, K., Peterson, D., Peterson, N., Stecher, G., Nei, M. and Kumar, S., 2011. MEGA5: Molecular Evolutionary Genetics Analysis Using Maximum Likelihood, Evolutionary Distance, and Maximum Parsimony Methods. Molecular Biology and Evolution, 28(10), pp.2731-2739. https://doi. org/10.1093/molbev/msr121

Tasma, I.M., 2015. Pemanfaatan teknologi sekuensing genom untuk mempercepat program pemuliaan tanaman. Jurnal Penelitian dan Pengembangan Pertanian, 34(4), pp.159-168. http://dx.doi.org/10.2 1082/jp3.v34n4.2015.p159-168

Widodo, D.H., Utomo, A.N., Ramadhani, A., Hasanah and Fitriah, A., 2018. Cara mudah membuat pohon filogenetik dengan Mega Software. Global Science. Malang. 18 p.

Widodo, M.S., Hasan, V., Mukti, A.T. and Kusuma, B., 2020. Distribution of Dwarf Snakehead Channa gachua Hamilton, 1822 (Teleostei, Channidae) on Brantas River Basin,
Indonesia. Ecology, Environment and Conservation, 26(2), pp.618-621. http://www.envirobiotechjournals. com/EEC/v26i220/EEC-22.pdf

Wigati, E., Sutarno and Haryanti, 2003. Genetic variation of Anggoli fish (Pristipomoides multidens) based on allozyme patterns. Biodiversitas Journal of Biological Diversity, 4(2), pp.73-79. https://doi.org/10.13057 /biodiv/d040201

Wirdateti, Indriana, E. and Handayani, 2016. Analysis on Mitochondrial DNA Cytochrome Oxidase I (COI) Sequences of Indonesia Slow Lories (Nycticebus spp.) as Marker to Improve Identification of Species. Jurnal biologi indonesia, 12(1), pp.119-128. https://jurnalbiologi. perbiol.or.id/home/article/95c4223 c-6d32-4e87-bf64-cb57e6e3a263 